\title{
マルチプロセッサシステムを用いた核融合 プラズマ位置形状制御システムの開発
}

\begin{tabular}{|c|c|c|c|c|c|c|c|c|}
\hline 正 員 & 近藤 & 育朗 & (原 研) & - 正員 & 村井 & 勝治 & （日 & 立 \\
\hline 亘 & 木村 & 豊秋 & （原 研） & - 正 員 & & & 日 & 立 \\
\hline & 栗 & III. & (原 研) & - 正員 & 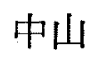 & 尚 & 日 & \\
\hline & & & (原 研) & - 非会員 & & & & \\
\hline & & & (原 研) & . & & & 日 & \\
\hline
\end{tabular}

\section{1. 緒 言}

核融合実用化にあたって，最も有望視されているト カマク型装置は，現在，核融合炣の前提となる臨界プ ラズマ条件の達成を目指す大形トカマク装置が，日・ 米・欧で運転されている段階にある。我が国では，日 本原子力研究所那珂研究所化拉いて，臨界プラズマ試 験装置 JT-60 か3昭和 60 年 4 月から運転開始され， 1

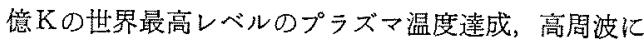
よるプラズマ電流駆動実験成功なざ，数々の成果をあ げている。

JT-60 はプラズマを発生させ閉じ込める本体を中 心片，閉じ込磁場コイル電源，加熱装置など多数の 設備から構成されており，これらの設備・機器を相互 に緊密に迹慗運転させて安定なプラズマを生成, 維持 する必要がある。この役目を担うのが全系制御設備で あり，JT-60 を構成する各設備制御システムの中枢上

\footnotetext{
Development of the Plasma Position and Shape Control System with Multiprocessor System. By Iktu Kondo, Member, Toyoaki Kimuta, Member, Ken-ichi Kurihara, Non-member, Makoto Matsukawa, Member, Yoichi Kawamata, Non-member (Japan Atomic Energy Research Institute), Katsuji Murai, Member, Tsutomu Matsuki, Member, Takahide Nakayama, Member, Akihiko Maeda, Non-member \& Kunio Moriyama, Non-member (Hitachi, L.td.)

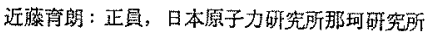

木村䇺秋：正員，日本原子力研究所那师研究听

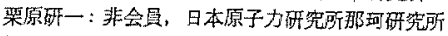

松川䧕：正員，日本原子加研究所那珂研究所

川俣隄一: 非会圆, 日本原子力研究所那珂研究所

㭙井腾治：正是，(株) 日立整作所大み加工場

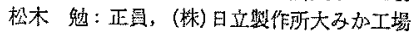

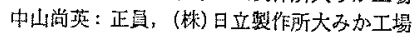

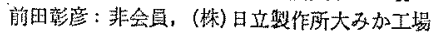

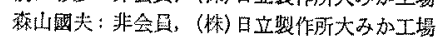

して，全設備を統括監視し，多様な実験運転計面任沿 った柔軟な実験制御を司っている。なかでも，プズ マ位置形状制御システムは, プラズマ諸量を锥㮣し て，プラズマ放電中てれらを衣定の值に維持制御する ものであり，プラズマ実験研究を遂行するにあた。 て，その基礎上なるプラズマの生成・維持に不可欠な 設備である。本システムの主要機能は，(1)プラズマ 位置形状検出信号皘分処理, 検出器信号誤差補正を含 む制御状態変数導出，（2)位置形状制御磁界之状態变 数の非干啮化や最適制御の導入を考慮した多変数つィ ードバック制御演算，（3）状態変数や指令值データの 保存である。

これらの機能は高速アレイプロセッサと制御用計算 機からなる3段パイプラインマルチプロセッサシステ ムによる值接ディジタル制御手法により実現した。 本論文では，核融合プラズマ位置形状制御システムム の機能，棈成扔よび主要開発技術について述べる。

\section{2. プラズマ位置形状制御システムに必要な 機能}

図1はプラズマ位置形状制御システムの開発方鈷を 示す。とのシステムは，臨界条件達成を目指す高べー

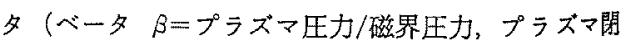
込效率を表す。) プラズマの位置形状を高速, 高精 度で所定の值に制御守ることを目指している。そのた め, 高 $\beta$ プラズマに対応した位置形状演算，補正演 算および状態変数之制御コイル磁界の非干渉化や最道 制御などの手法が可能な多変数制御方式を導入した， 再現性のよい高速，高精度プラズマ位置形状制御シス 


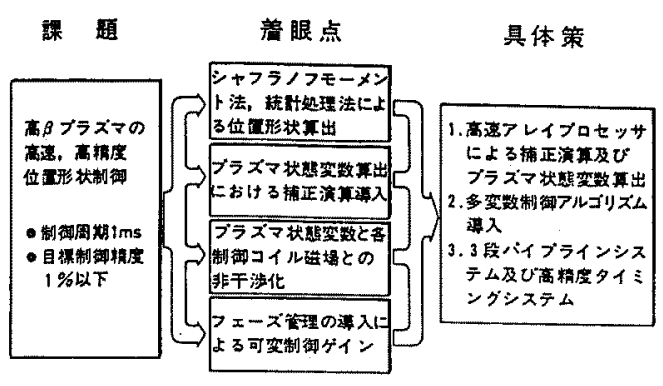

図 1 プラズマ位置形状制御システムの開発方針

Fig. 1. Development concept of the plasma position and shape control system.

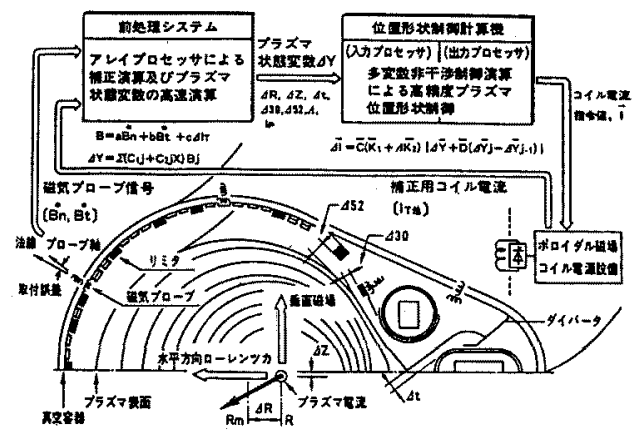

図 2 プラズマ断面および位置形状制御方式

Fig. 2. Structure of position and shape control with a cross-section of plasma.

テムを計画した。しかし，とれらの制御を行うために は, 膨大な制御演算を钽密记管理された制御周期の中 で行う必要があり, 従来の制御用計算機では必要な制 御周期 $1 \mathrm{~ms}$ を維持できない。そのため，アレイプロ セッサを制御状態变数導出の前処理システムとするマ ルチプロセッサによる 3 段パイプラインおよび高精度 タイミングシステムからなる制御システムを開発する こととした。ととに開発した制御方式はプラズマ断 面が円形の場合のみでなく、非円形, BEAN 形状の 場合にあ基本的に適用することができる。プラズマパ ラメータが異なる場合は，そのパラメータに刘応して 演算式を変換すればよい。また, ブラズマと真空容器 間間淂の制御については，統計的手法老用いているた め, システムに応じたシミュレーション検討が必要で ある。

以下にプラズマ位置形状制御に必要な状態量算出お よび制御方式について述べる。

図2はプラズマ断面贴上び位䇫形状制御方式走 क。

〈2・1 プラズマ位置形状検出 プラズマ位置形 状はトカマクプラズマ中を流机るプラズマ電流がつく
る磁界を磁気プローブで検出するととによって検出す るととができる。JT-60のプラズマ制御には，当初電 流密度の多重極モーメント之電流の作る磁界との間の 関係を利用する多重極モーメント法(1)上して知られる 方法を採用した。しかし，臨界プラズマの発生を目指 して，中性粒子入射や高周波加熱に上り高温，高密度 プラズマの制御を行う場合，以下の間題点がある。

（1）多重極モーメント法で求めたプラズマ電流中 心位置は，プラズマの高 $\beta$ 化红伴い，プラズマの幾何 学的中心（最外款磁気面の中心）よりトロイダル効果 口上に外側方向に移動する。（図2 $A R$ 参照）

（2）プラズマ中心位犆の制御に加えてより本澌的 なプラズマと真空容器との間隙を制御するため, 新た な状態変数とその検出式が必要である。(図 $2 \Delta 52$, $\triangle 30, \Delta \mathrm{t}$ 参照)

そこで, 本システムではプラズマ水平位置検出方法 よして多重極モーメント法に換えて $\beta$ 依存性を持たな いシャフラノフモーメント法(2)を新しく適用する。な 拉，プラズマ垂直位圈 $\Delta Z$ の算出には，この上うな $\beta$ 値の効果はないので多重極モーメント法を使用す る。シャフラノフモーメント法では, プラズマの幾何 学的中心の水平位置 $R$ 进次式により求める。

$$
\begin{aligned}
R= & \left(r_{p}^{2} / 4 R_{m}\right)\left\{\left(r_{m}^{2} / r_{p}{ }^{2}-1\right)-2 \ln \left(r_{p} / r_{m}\right)\right\} \\
& +\left(r_{m} / 2\right)\left\{\lambda_{1}\left(1-r_{p}^{2} / r_{m}^{2}\right)-\mu_{1}(1\right. \\
& \left.\left.+r_{p}^{2} / r_{m}^{2}\right)\right\}+C_{M} I_{M} / I_{p}+R_{m} \ldots \ldots(1)
\end{aligned}
$$

ことで, $R_{m}:$ 真空容器中心水平位置, $r_{p}: フ^{\circ}$ ラズマ小半径, $r_{m}: R_{m}$ 少ら磁気プローブま での小半径

$$
\begin{aligned}
\lambda_{1}= & \left(\pi r_{m} / \sqrt{3} \mu_{0} I_{p}\right)\left(B t_{1}-B t_{3}-B t_{4}+B t_{6}\right)-I / \\
& 2 I_{p} \\
\mu_{1}= & \left(\pi r_{m} / 3 \mu_{0} I_{p}\right)\left\{B n_{1}-B n_{3}-B n_{4}-B n_{6}+2\right. \\
& \left.\left(B n_{2}-B n_{5}\right)\right\}-3 I_{M} / 2 I_{p}
\end{aligned}
$$

$I_{p}:$ プラズマ電流, $I_{M}:$ ダイバータコイル電 流, $C_{M}$ : 定数。 $B t_{1 \sim 6}:$ ポロイダル磁界接線力 向成分， $B n_{1 \sim 6}$ : ポロイダル磁界法線方向成 分， $\mu_{0}$ : 真空透磁率である。(図 2 参照)

次に,プラズマと真空容器間間隙の制御については, MHD 平衡解析によるプラズマ平衡配位の状態変数 $\Delta Y$, 磁界測定量 $B$ ，および補正項 $X$ を

$$
\Delta Y=\sum_{j=1}^{N}\left(C_{1 j}+C_{2 j} X\right) B_{j}
$$

のように多項式の形で結合し，保数 $C_{1 j}$ 求よび $C_{2}$, をプラズマの平衡データベースから重回帰分析により 求統計処理法 ${ }^{(3)}$ を用いる。ここで， $B_{j}$ は $B t_{1-6}$, $B n_{1-6}, X$ は $I_{M} / I_{P}$ または $I_{Q} / I_{P}$ であり, $\Delta Y$ として ダイバータ部セパラトリスク位置 $\Delta t, 30^{\circ}$ リミタ間 
隙 $\Delta 30,50^{\circ}$ リミ夕間隙 $\Delta 52$ を採る。これら各プラ ズマの状態は図 2 に示すように制御用磁界がプラズマ 電流に与えるローレンッカを利用して所定の值に制御 される。

(1)式の $B t_{1 \sim 6}, B n_{1 \sim 6}$ 上(2)式の $B_{j}$ は, 磁気プ ローブ信号より，(1)式のIPはロゴスキーコイル信 号より各々测定される。しかし, 実際には各検出器信 号化種々のエラー成分加合まれている。例えば，図2 に示す上うに, 法線方向成分 $B n_{1}$ 用磁気プローブ軸 が，真の設定位置に対しある傾きをむって取付けられ たとすれば，磁気プローブ出力信号 $B n^{*}{ }^{*}$ は，接線方 向成分 $B t_{1}$ および $B n_{1}$ と $B t_{1}$ 亿詨して独立なトロイ ダル磁界 $B T(\infty$ トロイダルコイル電流 $I T)$ を受け る。これはすべての磁気プローブ出力信号 $B n{ }^{*} \sim B n 6^{*}$ および $B t_{1}^{*} \sim B t_{6}{ }^{*}$ に対して同様であり，逆化真の磁 界成分 $B n_{1} \sim B n_{6}, B t_{1} \sim B t_{6}$ は，

$$
B n_{1}=a B n^{*}+b B t^{*}+c \Delta I_{T}
$$

の形で補正する必要がある。これら $a, b, c$ の値はプ ローブごとに構造的に決まる定数である。一方，プラ ズマ電流計測用ロゴスキーコイル出力 I ROG に注各制 御磁界発生用コイル電流の影響が含まれている。

そこで真のプラズマ電流 $I_{P}$ を求めるため, 次の補 正が必要となる。

$$
\begin{aligned}
I_{p}= & I_{\mathrm{ROG}}+K_{V} I_{V}+K_{\mathrm{H}} I_{H}+K_{Q} I_{Q}+K_{M} I_{M} \\
& +K_{T} \Delta I_{T} \ldots \ldots \ldots \ldots \ldots \ldots \ldots \ldots \ldots \ldots \ldots \ldots \ldots \ldots \ldots \ldots \ldots \ldots \ldots \ldots \ldots
\end{aligned}
$$

ここで，IVは垂直磁䣎コイル電流， $I_{H}$ は水平磁界 コイル電流， $I_{Q}$ は四重極磁界コイル電流， $I_{M}$ はダイ バータコイル電流, $K_{V}, K_{H}, K_{Q}, K_{M}, K_{T}$ は各コイル 電流江対する補正你数である。

プラズマ状態变数は，(3)，(4)式による補正演算を 行った後，補正された検出器信号を用いて(1)，(2) 式に基づいて制御周期ごとに算出しなりればならな い。こ扎らの演算は，通常のプロセス制御用計算機で は $1 \mathrm{~ms}$ 以上かかるため，高速のアレイプロセッサを 導入して演算処理時間の短縮を図ることとする。

〈2・2〉 プラズマ位置形状多变数制御 プラズマ 位置形状制御において，制御目標值は上位計算機シス テムから実時間で与えら机る。その後，因2 亿示す上 うに位置形状制御計算機は, これらの目標值に対し, 前愐に示した前処理システムで求めた状態変数を愲還

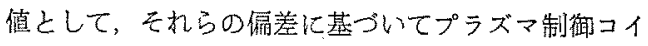
ルのの電流指令值の演算を行いポロイダル磁界コイル 電源設備へ送出する。

従来のシステムでは，1個の制御コイル電流指命値 には 1 個のプラズマ状態変数を対応させていた。すな わ方，(1)，(2)式によって算出した㴆還值である各
プラズマ状態变数と制御目標値との偏差 $\Delta Y$ k基了 き, 制御コイル電流指令值 $I_{j}^{\text {rei }}$ を次の上うに決定す る。

$$
\begin{aligned}
& I_{j}^{\mathrm{ref}}=I_{j}^{\text {base }}+\Delta I_{j} \\
& \Delta I_{j}=C\left\{\Delta Y_{j}+D\left(\Delta Y_{j}-\Delta Y_{j-1}\right)\right\}
\end{aligned}
$$

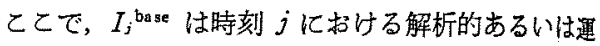
転実績によって定めるプレプログラムコイル電流值ま たはコイル電流現状值，Cは比例制御ゲイン，Dは敨 分制御ゲインである。 $I_{j}^{\text {base }}$ はシミュレーションコー ドによって解析的に求めることは可能であり，解析的 に求めたプレプログラム値によって運轱し，その運転 実績に基づいて補正を行っている。 $I_{j}^{\mathrm{ret}}$ と $\Delta Y$ は, 垂直磁界コイル電流 $I_{V}$ とプラズマ水平位置偏差 $\Delta R$, 水平磁界コイル電流 $I_{H}$ とプラズマ垂直位置挶差 $\Delta Z$, 四重極磁場コイル電流 $I_{Q}$ 之 $30^{\circ}$ リミタ間腺 $\Delta 30, タ^{\circ}$ イバータコイル電流 $I_{M}$ とダイバータ部セパラトリク ス位置 $\Delta t$ の上うに 1 対 1 亿対応する。

しかし，実際のシステムに抵いては，各コイル電流 值とプラズマ状態変数との関係は必ずしあ 1 対 1 亿な っていない。従って、プラズマの位置形状平衡制卸を より精度よく行うためには，非干渉化や最息制御など の手法が適用できる多变数フィードバック制御方式を 導入する必要がある。

そこで(5)式のスカラ一量 1 個の状態変数之目標值 の偏差 $\Delta Y_{j}$ のかわりに, 複数の状態变数と制御目標 値との偏差べクトル $\Delta \vec{Y}_{j}$ を定義する。

$$
\Delta \vec{Y}_{j}=\left(\begin{array}{c}
\Delta R_{j}^{\mathrm{ref}}-\Delta R_{j}{ }^{\mathrm{obs}} \\
\Delta Z_{j}^{\mathrm{ref}}-\Delta Z_{j}{ }^{\mathrm{obs}} \\
\Delta 30_{j}^{\mathrm{ref}}-\Delta 30_{j}{ }^{\mathrm{obs}} \\
\left(\text { または } \Delta 52_{j}^{\mathrm{ref}}-\Delta 52_{j}^{\mathrm{obs}}\right) \\
\Delta t_{j}^{\mathrm{ret}}-\Delta t_{j}{ }^{\mathrm{obs}}
\end{array}\right) \cdots
$$

ここで添字 ref は指令値，obsは错測值を表す。

一方, JT-60において制御可能な操作量, すなわ方 ポロイダルコイル電流は，IV，IH，IQ，IM の4 種類で あり $\vec{I}$ と定義する。

$$
\vec{I}=\left[\begin{array}{c}
I_{V} \\
I_{H} \\
I_{Q} \\
I_{M}
\end{array}\right]
$$

操作量の次元は 4 のため, (7)式の状態变数べクト ルのうち，独立㳊制御可能な要素は最大 4 個である。

そのため，実機においては $30^{\circ}$ リミ多間淂 $\Delta 30$ と $50^{\circ}$ リミ夕間隙 $\Delta 52$ のう方 1 個学選択して制御を行 う。プラズマ位置形状制御計算機で実行する制御演算 式在次に示す。

$$
\vec{I}_{j}=\vec{I}_{j}^{\text {base }}+\Delta \vec{I}_{j}
$$




$$
\begin{aligned}
\Delta \vec{I}_{j}= & \overleftrightarrow{C}\left(\overleftrightarrow{K}_{1}+\Lambda \overleftrightarrow{K}_{2}\right)\left\{\Delta \vec{Y}_{j}+\overleftrightarrow{D}\left(\Delta \vec{Y}_{j}\right.\right. \\
& \left.\left.-\Delta \vec{Y}_{j-1}\right)\right\} \ldots \ldots \ldots \ldots \ldots \ldots \ldots \ldots \ldots \ldots \ldots \ldots
\end{aligned}
$$

ここで, $\vec{I},^{\text {base }}$ は(5)式の場合と同様プレプログラ 么による電流指令值であり， $\vec{C}$ 江 4 行 4 列比例制御ゲ

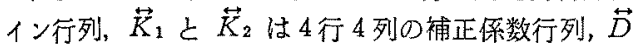
は 4 行 4 列微分制御ゲイン行列である。補正係数行 列は，高 $\beta$ ブラズマ生成時のプラズマ $\beta$ 值に対する 各状態変数の依存性をシャフラノフラムダA 亿よっ て比例制御保数に反映させるすのである。な挍，比例 制御ゲイン行列の第 3 列は, 状態変数 $\Delta 30$ または $\Delta 52$ 亿対忍しており，選択するととができる。

な挍，(8)式の運用にあたっては，1放䉓の間にプ ラズマ状態が大幅に変化するため,プラズマの制御を 最道に行うようにプラズマの条件に岕じて各制御ゲイ ンを拣時間で変更することを可能とすることが必要で ある。

\section{3. プラズマ位置形状制御システムの構成}

図3は臨界プラズマ試験装置 JT-60 のシステム構 成を示す。JT-60 はプラズマを発生させ閉じ込める本 体を中心纪, 閉じ込的磁界コイル電源, 加熱装置など

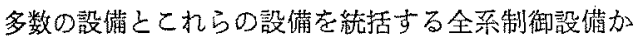
らなる。全系制御設備は，標準化インターフェース CAMAC およびタイミングシステムを通して全設備 を監視制御するとともに，プラズマ位置形状や温度， 密璂の制御を行って, 安定なプラズマ生成, 維持を司 っている。

図4はプラズマ制御システムの構成を示す。プラズ マ特性制御計算機は，後述する位置形状制御のための 目標檤を位置北状制御計算機汇与えるとともに，プラ ズマ温度, 密度の特性演算を行って, ガス注入量や加 熱入力量の指命值を与えプラズマ温度, 密度のフィー ドバック制御を行う。プラズマ位置形状制御は，前処

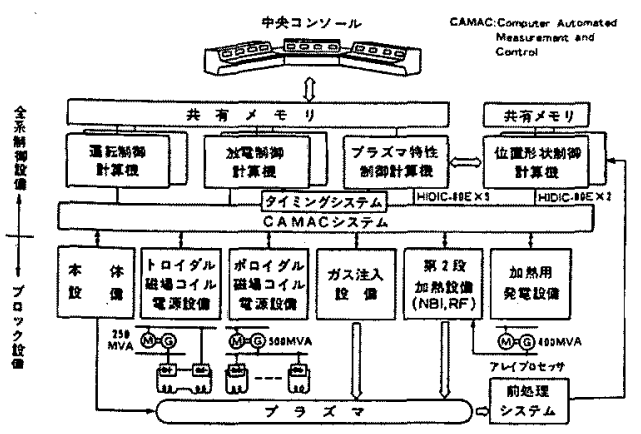

图 3 JT-60 システム構成図

Fig. 3. System configuration of JT-60.

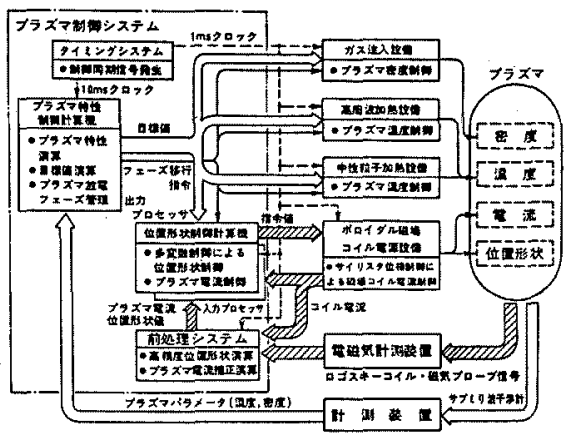

図 4 プラズマ制御システム機能權成

Fig. 4. Block diagram of the plasma control system.

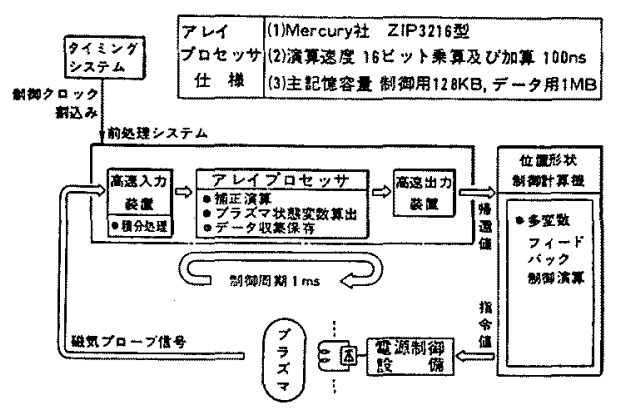

因 5 プラズマ位置形状制唂システムへの アレイプロセッサの適用概念図

Fig. 5. Application of an array processor to the plasma position and shape control system.

理システムによって磁気プローブ信号の積分やその愦 差補正およびプラズマ位置珍状演算を行い，位置形状 制御計算機でプラズマ位置形状フィードバック制御演 算を行ってポロイダル磁界コイル電源化指令を与える ことによって実現する。更に，乙れらの制御の再現性 它高度に維持するための高精紊タイミングシステムに 上って，全システムの同期遇檕安行っている。

以下，乙机らプラズマ制制の中枢となる位置形状制 御を司る本システムの開発内容を述べる。

〈3.1〉プラズマ位置形状制御前処理システム

(1) 前処理システムへのアレイプロセッサの適用 プラズマ状態变数の算出を高速で行うため, 前処理 システムへアレイプロセッサ蓄入して演算処理時閣 の短縮を図った。

図5は前処理システムへのアレイプロセッサの通用 概念図である。前処理システムにアレイプロセッサ （ZIP 3216）䎞適用し，〈2・1〉節に述べた演算にアレ イプロセッサの有する乘算および加算 $100 \mathrm{~ns}$ という 高速性能を十分活用するためには，二つの課題を解決 
する必要があった。その第1は，アレイプロセッサに は位置形状榆出のための磁気プローブ信号やロゴスキ ーコイル信号を直接高速入力する必要があり，また， 磁気プローブなどの出力信号は, 検出器の原理上微分 された信号であるため，高速入力装置において積分処 理を行い元の磁界成分を求める必要があった。第 2 は，アレイプロセッサは位置形状制御計算機之共に， 外部のタイミングシステムによって生成された制御ク ロックに笽密侸同期して動作する必要があった。以 下，乙れらの解決策について述べる。

（2）高速入力装置図6は高速入力装置に招け るディジタル積分方式を示す。磁気プローブは，プラ ズマ電流による磁界 $B$ の変化分すなわち鞂分值を信号 として出力する。そのため, 積分処理を行って元の磁 界信号を求め, プラズマ状態变数演算を行う必要があ る。こてでは，皘分結果のドリフトがなく，データ処 理が容易な見地から電圧周波数 (VF) 変換器とパル スカウンタを組合わせたディシタル皘分方式を開発し た。

磁気プローブからの信号はVF 変換器によりパル ス列に変換される。ここで応答性向上のため, 出力パ ルス最大周波数を $1 \mathrm{MHz}$ 江選択した。更に，負側の 信号も皘分できるようにするため，バイアスを重眰し てアップダゥンカゥンタのアップ㑡に入力して皘分す る。

一方，バイアス分も同時に積算されるため，バイア

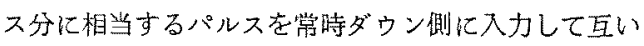
に相殺して積分動作させるようにした。積分結果は制 御クロックごとにアレイプロセッサから直接読み出 妾。

この方式により，フルスケールに対して 0.1\%の高

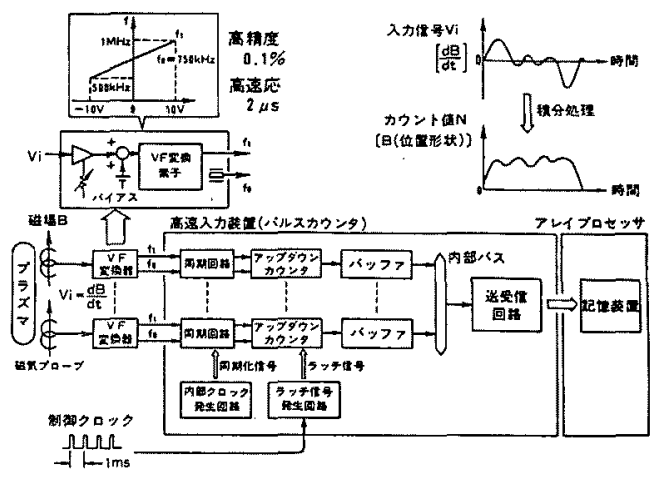

图 6 高速入力菨置におけるディジタル 皘分方式

Fig. 6. Digital integration method with the high-speed signal input device.
精度, $2 \mu \mathrm{s}$ の高速応答を有するディジタル皘分加可能 となり，高精度アルゴリズムと合せて位固形状演算棈 度 $0.1 \%$ を実現した。

（3）アレイプロセッサへの高速割込み処理 困 7 は制御クロックのアレイプロセッサへの高速割込み 処理方式を示す。アレイプロセッサは位置形状制御計 算機と共に湤密に同期して実時間制御を行う必要が る。そのため, アレイプロセッサはタイミングシステ ムによって戦密管理された $1 \mathrm{~ms}$ 制御クロックに基 ついて繰返し処理を起動するようにした。アレイフ ロセッサは，一般の制御用計算機のような割入み信号 に対するべクタリング処理機能をもたないため，実時 間処理中は常時 DMA リクエスト待ち状態としてお き，制御クロックにより入力装置からアレイプロセッ サを直接起動するようにした。そのため，高速入出力 装置やアレイプロセッサ間のデータ転送を制御するコ ントローラボードを開発し, 制御クロックを直接高速 入力装置に入力してデータラッチさせた後, DMA リ クエストを発行させるようにした。一方, アレイプロ セッサは，実時間処理を開始した後はデータによって 起動される状態,すなわち, DMA リクエスト待ち状 態となっている。この状態で高速入力装置にデータが 用意され，DMAリクエストが発行されるとアレイプ ロセッサはデータ入力を行い, 補正演算, プラズマ状 態変数演算の一連の処理を行い, その結果を出力す る。

以上，述べたようにアレイプロセッサへの制御クロ ックの高速割込みを実現し，制御クロック入力からプ ラズマ状態変数出力までの処理時闎を $210 \mu \mathrm{s}$ とする ことができた。

〈3・2〉プラズマ位置形状制御計算機システム 図8はプラズマ位置形状制御を高速で行うための，

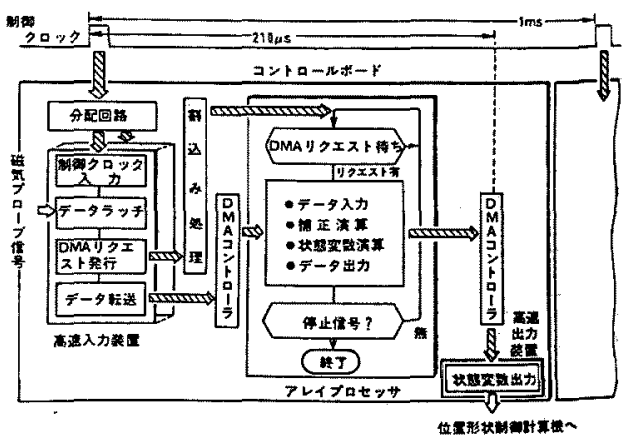

図 7 アレイプロセッサへの高速割迂る処理

Fig. 7. Interruption procedure in the array processor. 


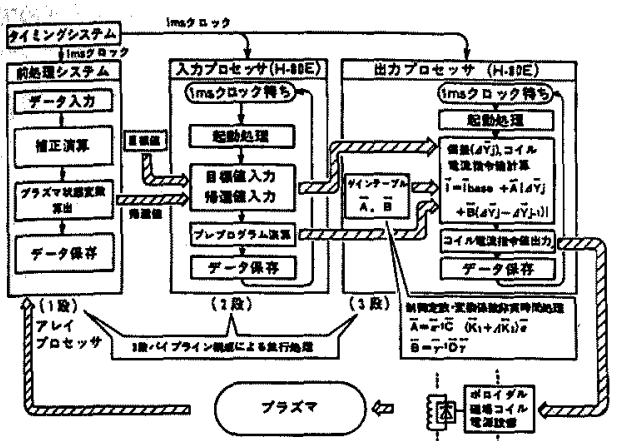

图 8 多変数フィードバック制御高 速演算処理方式

Fig. 8. High-speed calculation for the multivariable feedback control.

多変数フィードバック制御高速演算処理方式を示す。 〈2*2〉節に述べたように多変数フィードバック制硬演 算は，4行 4 列のマトリクス演算を合む。この多量の 演算を高速処理するため，あらかじめ演算可能な制御 定数，工学值变換係数は，制御グイン $\overleftrightarrow{A} ， \overleftrightarrow{B}$ としてプ ラズマ制御開始前に非実時間好理し，実時間で行うフ ローティング演算命令を集約して最小化した。また， 多变数フィードバック制御演算において，プレプログ ラム演算，またはデータ保存なじ 2 台の計算機で型行 処理できる部分があることに着目して，多変数フィー ドバック制御演算を 2 台の計算機に機能分割し，前処 理システムを含む 3 段パイプライン構成として並行処 理による高速化を計った。

図8において，1段目は前処理システムプイプロ セッサにより，プラズマ状態变数算出を行う。2没目 は入力プロセッサとして制御用計算機 ( $\mathrm{H}-80 \mathrm{E})$ を用 いて位置形状の目標值，帰還值の入力および単位変換 在行う。3段目は出力プロセッサにより，多変数つ イードバック制御演算を行い，コイル電流指令值を求 め,ポロイダル磁界コイル霓源設備に出力する。

図9はこれら3段パイプラインシステムの動作をタ イムチャートで表したものである。タイミングシスデ ムが発生する $1 \mathrm{~ms}$ 制御クロックは，前処理システム 用のクロック 1，入力プロセッサ用のクロック 2 ,

出力プロセッサ用のクロック3よりなる。クロック 2 は前姏理システムの演算終了時間を考虑した時間逑れ をむたせ，また，クロック3は入力プロセッサの演算 終了時間を考慮した時間遮れをむたせて $1 \mathrm{~ms}$ 周期で ブラズマ制御中パルスを速続発生さ甘ている。このよ うにして，前処理システムの演算結果がむだ封間なく 入力プロセッサに入力して演算に利用され，同㭗に，

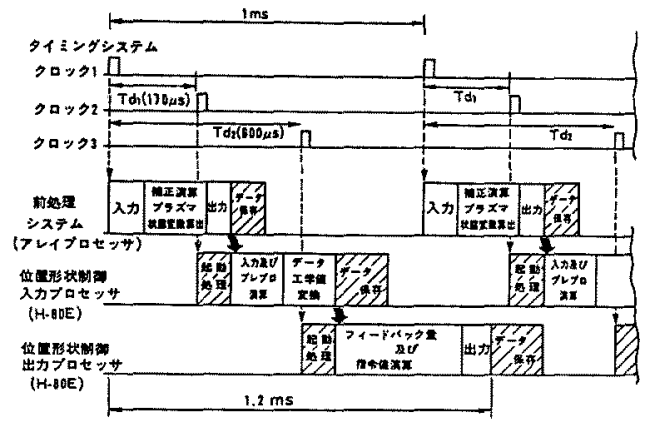

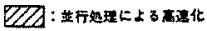

図 93 段パイプラインシステムの勳作

Fig. 9. Time chart of the three-step pipelined system.

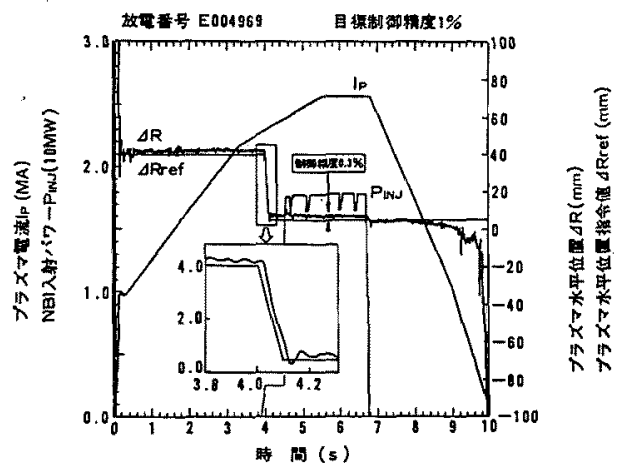

図 10 プラズマ制御結果

Fig. 10. Result of the plasma position and shape control.

入力プロセッサ演算結果もむだ時間なく出力プロセッ サに利用されて，最短時間で前処理システムから山力 プロセッサにデータが流れる。また，データ保存や起 動処理は，並行好理することができる。このようにし て，従来の制御用計算機(H-80E) 1 台で零行した場 合， $2.5 \mathrm{~ms}$ 要寸ると推定された多量の演算炕理が, $1.2 \mathrm{~ms}$ の高速で奉行するととが可能となった。更に， 出力プロセッサ演算中に前処理システムには次の制御 周期の入力が可能であり，システム全体しして $1 \mathrm{~ms}$ 周期で高速動作させるととが可能である。

\section{4. 試験結果}

図 10 は臨界プラズマ試䮖装置 JT-60における本シ

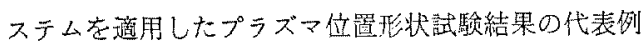
を示す。との例は，最大プラズマ電流 $2.6 \mathrm{MA}$ 放電

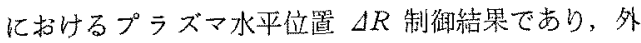
乱となる中性愔子入射加熱を行っている期間を含み， 
放電時間のほとんど全域にわたり制御精度の目標值 1\% 以下を十分満足し，安定なプラズマを得ている。

垂直位置 $\Delta Z, 30^{\circ}$ リミ夕間隙 $\Delta 30,50^{\circ}$ リミ夕間 陌 450 , プラズマ電流 $I_{P}$ なども制御周期 $1 \mathrm{~ms}$ で制 御目標值 $1 \%$ 以内制御されている。JT-60は, 昭 和 62 年 6 月から本格的なプラズマ加熱実験を開始し, 本プラズマ制御システムを用いて，臨界プラズマ条件 達成汇向けて実駼を進めている。

\section{5. 結言}

跕界プラズマ試験装置 JT-60 のプラズマ位置形状 制御のため, アレイプロセッサを導入した高精度（精 度 $0.1 \%$ 以下）で, 高速（処理時間 $210 \mu \mathrm{s}$ ）の位置 形状検出，招よび多変数フィードバック制御方式に上 る制御周期 $1 \mathrm{~ms}$ の高精度（精度 $1 \%$ 以下）位犆形状 制御システムを開発した。とのシステムは，JT-60に 適用して安定で再現性の上い高温, 高密度プラズマの
生成に成功し，臨界条件の達成江向りて実験を進めて いる。また，開発したシステムは，核瀜合プラズ、制 御技術の基本となるあのであり，その開発成果を踏ま えて，次期実験哣を目指した核融合プラズマ制御技術 の開発仅組んでいく考えである。

終りに，本システムの開発にあたり，御指導およひ 御協力いただいた関係各位に心から謝意を表す次第て ある。

(昭和 62 年 8 月 25 日受付)

\section{文献}

（1）相川・小方・铪木：「磁気プローブによる位置・断面形㧋松 出」JAERI-M6931 (昭 52-2)

(2) H. Ninomiya, et al.: "Estimation of Plasma Position and $\beta_{p}+t_{i} / 2$ Magnetic Measurements under High $\beta$ Condition in JFT-2", JJAP, 21, 1323 (1982)

(3) N. Hosogane, et al.: "Method for Measuring Divertor configuration Parameters for Feedback Control in JT60", Nucl. Fus., 26, 657 (1986) 